\title{
Biomechanical technology of injury prevention in the training of specialists in physical education and sports
}

\author{
Kozin S.V., ${ }^{1,2}$ \\ ${ }^{1}$ Aimed Klnik, Israel \\ ${ }^{2}$ Alef Clinic, Kharkiv, Ukraine
}

DOI: https://doi.org/10.34142/HSR.2021.07.02.06

\section{How to Cite}

Kozin SV. Biomechanical technology of injury prevention in the training of specialists in physical education and sports. Health, Sport, Rehabilitation. 2021;7(2):65-76. https://doi.org/10.34142/HSR.2021.07.02.06

\begin{abstract}
Purpose: to develop and experimentally test the biomechanical technology of injury prevention of future specialists in physical education and sports in the process of professional training (rock climbing for example).

Material and Methods. The participants of this study were 84 male students engaged in amateur climbing aged 18-19 years. All athletes were also students of physical education faculties of Ukrainian universities; 40 athletes were in the experimental group and 44 athletes were in the control group. The biomechanical technology for injury prevention in the training of specialists in physical education and sports has been developed on rock climbing for example. Developed biomechanical technology for injury prevention contains 3 areas: 1 - theoretical; 2 - analytical; 3 - practical. Injury risk (incidence) was defined as the number of injuries to the total number of athletes in the analyzed group. Relative risk (incidence rate ratio) was determined by the ratio of risk in the control group to the risk in the experimental group. The chance of injury was defined as the ratio of the number of injuries to the number of uninjured athletes in the analyzed group. The relative chance (Odds Ratio) was defined as the chances of injury in the control group to the chances of injury in the experimental group. These indicators were determined separately for low, medium and severe finger injuries.

Results. The applied technology of injury prevention significantly influences the reduction of the number of injuries of athletes - future specialists on the physical education and sports (on rock climbing for example). It is established that the application of the developed technology of injury prevention reduces the risk of finger injuries: low complexity - in 2.364 times $(95 \% \mathrm{Cl}=0.925-6.041, \mathrm{P}>0,05)$ times; medium complexity - in 3.333 times $(95 \% \mathrm{Cl}=1.001-11.096, \mathrm{P}$ (Fisher) $=0.030)$; high complexity - in 8.182 times $(95 \% \mathrm{Cl}=1.084-61.749, \mathrm{P}$ (Fisher) $=0.011)$.

Conclusions. The application of the developed biomechanical technology of injury prevention in the process of training specialists in physical education and sports significantly reduces the risk of injury to students.

Key words: injury, prevention, students, rock climbing, education
\end{abstract}




\section{Анотація}

Козін С.В. Біомеханічна технологія профілактики травматизму при підготовці спеціалістів 3 фізичного виховання і спорту

Мета: розробити і експериментально обґрунтувати біомеханічну технологію профілактики травматизму майбутніх фахівців з фізичної культури і спорту в процесі професійної підготовки (на прикладі скелелазіння).

Матеріал і методи. Учасниками дослідження були 84 студента чоловічої статі, що займаються скелелазінням на аматорському рівні, у віці 18-19 років. Всі спортсмени також були студентами факультетів фізичного виховання українських вузів. В експериментальну групу ввійшли 40 спортсменів, а в контрольну - 44 спортсмена. Була розроблена біомеханічна технологія профілактики травм при підготовці фахівців з фізичного виховання і спорту на прикладі скелелазіння. Розроблена біомеханічна технологія профілактики травм містить 3 напрямки: 1 теоретичне; 2 - аналітичне; 3 - практичне. Ризик (інцидентність) отримання травми визначався як відношення кількості травм від загальної кількості спортсменів в аналізованої групі. Відносний ризик (коефіцієнт інцидентності) визначався ставленням ризику в контрольній групі до ризику в експериментальній групі. Імовірність отримання травми визначалася як відношення кількості травм до кількості нетравмованих спортсменів в аналізованої групі. Відношення шансів визначалося як шанси травми в контрольній групі до шансів травми в експериментальній групі. Ці показники визначалися окремо для травм пальців легкої, середньої та важкого ступеня.

Результати. Застосовувана технологія профілактики травм суттєво впливає на зниження травматизму спортсменів - майбутніх фахівців з фізичного виховання і спорту (на прикладі скелелазіння). Встановлено, що застосування розробленої технології профілактики травм знижує ризик травм пальців рук: низької складності - в 2,364 рази $(95 \% \mathrm{Cl}=0,925-6,041)$; середньої складності - в 3,333 рази $(95 \% \mathrm{Cl}=1,001-11,096, \mathrm{P}($ Fisher) $=0,030)$; високої складності - в 8,182 рази (95\% Cl = 1,084-61,749, Р (Фішер) =0,011).

Висновки. Застосування розробленої біомеханічної технології профілактики травматизму в процесі підготовки фахівців з фізичного виховання і спорту значно знижує ризик травматизму студентів.

Ключові слова: травми, профілактика, студенти, скелелазіння, освіта.

\section{Аннотация}

Козин С.В. Биомеханическая технология профилактики травматизма при подготовке специалистов по физическому воспитанию и спорту

Цель: разработать и экспериментально обосновать биомеханическую технологию профилактики травматизма будущих специалистов по физической культуре и спорту в процессе профессиональной подготовки (на примере скалолазания).

Материал и методы. Участниками исследования были 84 студента мужского пола, занимающихся скалолазанием на любительском уровне, в возрасте 18-19 лет. Все спортсмены также были студентами факультетов физического воспитания украинских вузов. В экспериментальную группу вошли 40 спортсменов, а в контрольную - 44 спортсмена. Была разработана биомеханическая технология профилактики травм при подготовке специалистов по физическому воспитанию и спорту на примере скалолазания. Разработанная биомеханическая технология профилактики травм содержит 3 направления: 1 - теоретическое; 2 аналитическое; 3 - практическое. Риск (инцидентность) получения травмы определялся как отношение количества травм от общего количества спортсменов в анализируемой группе. Относительный риск (коэффициент инцидентности) определялся отношением риска в контрольной группе к риску в экспериментальной группе. Вероятность получения травмы определялась как отношение количества травм к количеству нетравмированных спортсменов в анализируемой группе. Отношение шансов определялось как вероятность травмы в контрольной группе к шансам травмы в экспериментальной группе. Эти показатели определялись отдельно для травм пальцев легкой, средней и тяжелой степени.

Результаты. Применяемая технология профилактики травм существенно влияет на снижение травматизма спортсменов - будущих специалистов по физическому воспитанию и спорту (на примере скалолазания). Установлено, что применение разработанной технологии профилактики травм снижает риск травм пальцев рук: низкой сложности - в 2,364 раза $(95 \% \mathrm{Cl}=0,925-6,041)$; средней сложности - в 3,333 раза $(95 \% \mathrm{Cl}=1,001-11,096, \mathrm{P}$ (Fisher) =0,030); высокой сложности - в 8,182 раза $(95 \% \mathrm{Cl}=1,084-61,749, \mathrm{P}$ (Фишер) =0,011).

Выводы. Применение разработанной биомеханической технологии профилактики травматизма в процессе подготовки специалистов по физическому воспитанию и спорту значительно снижает риск травматизма студентов.

Ключевые слова: травмы, профилактика, студенты, скалолазание, образование. 


\section{Introduction}

The process of training specialists in physical education and sports is built in such a way that students have a large number of practical disciplines in various sports along with the chosen [1]. In practical classes, students learn technical skills, develop physical qualities, and learn to conduct classes not only in the chosen sport, but also in others. Therefore, the schedule of students future specialists in physical education and sports is built in such a way that in one day there can be 2-3 pairs of practical classes in different sports, and in the evening - training in the chosen sport. This puts a heavy burden on the cardiovascular system, which overtraining creates the conditions for injury.

In addition, each sport has its own characteristics $[2,3]$. When mastering the basics of a particular sport from childhood, the process of learning motor skills is easier compared to adulthood, when the sensitive periods of natural learning are over. And so the nervous system and musculoskeletal system of students with mastery of skills in various sports receive a heavy load. It should be noted that different movements in their biomechanical structure require the formation of different connections in the nervous system, and this is quite a difficult task. And the constant switching from one movement to another, which occurs when changing the type of activity, chaotic activity of the nervous system, and, accordingly, the musculoskeletal system. This creates the conditions for increased injuries. That is why the question of developing such learning technologies that will provide reliable prevention of injuries to students - future professionals in physical education and sports.

Currently, the role of physical culture and sports as the most powerful means of physical development, prevention of various diseases, recovery from illness. Sports contribute to the increase of motor intelligence, the development of psychological qualities that are necessary for building a career, the manifestation of individuality, success in all spheres of activity. Of particular importance is the importance of sports for students. However, sports are also accompanied by injuries of varying severity. This often leads to a large amount of time spent recovering from injuries, skipping classes, psychological problems [4-7].

In this regard, the problem of injuries to students in sports is widely covered in modern literature. The authors mainly pay attention to the registration of injuries of varying severity in different sports under different circumstances [8-11].

To analyze the number of students' injuries in the world, studies are carried out in various sports. For example, Asperti, et al. [12] found that Brazilian students engaged in amateur sports. traumatic impact was defined as the participation of one amateur student in one workout or game, and was expressed as the impact on the athlete (A-E). Injury rates are significantly higher in games (13.13 injuries per 1,000 student-athletes who participated in training or games $(\mathrm{AE}), 95 \%$ confidence interval $=10.3-15)$ than in training (4.47 injuries per 1,000, 95\% confidence interval $=3.9-5.1)$. The mechanisms that accounted for the most injuries in games and training were contact $(52.9 \%)$ and non-contact (54.5\%). Ankle sprains were the most common injury (18.2\% of all reported injuries). There was also a relatively high incidence of anterior cruciate ligament injuries $(0.16$ injuries per 1,000 student-athletes who participated in training or games (A-E)). Asperti, et al. [12] concluded that Brazilian amateur students are at high risk for non-contact injuries such as ankle sprains and anterior cruciate ligament injuries. Also indicate the highest prevalence of injuries of the distal parts of the lower extremities (ankle joint and knee) during sports [13]. Burchard, et.al. [13] found that most schoolrelated injuries occur in school sports, especially ball sports. The distal extremities were mainly injured.

In a study by Clifton, et al. [14] describes the epidemiology of injuries received in basketball by high school girls in the period from 2005-2006 to 2013-2014 school years and student women's basketball in the period from 2004-2005 to 20132014 school years. Injuries were recorded through an online sports surveillance program. The online high school reporting system documented 2,930 injuries with loss of working time over 24 hours during 1,609,733 workouts and games; The National University Sports Association's Injury Monitoring Program recorded 3,887 injuries with a loss of time of more than 24 hours during 783,600 workouts and games. Injury rates were higher in college than in high school (4.96 vs. 1.82 / 1000 training and games; injuries (IRR) $=2.73 ; 95 \%$ confidence interval $(\mathrm{CI})=2.60,2.86)$. The level of injuries was higher in competitions than in training, both for high school students (injury index $($ IRR $)=$ 3.03; 95\% confidence interval $(\mathrm{CI})=2.82,3.26$ ) and for students (injury index) IRR) $=1.99 ; 95 \%$ confidence interval $(\mathrm{CI})=1.86,2.12)$. The most common injuries at both levels were sprains, concussions, and sprains of muscles and tendons. Most of the injuries affected the knees, head and face. These injuries were often caused by contact 
with another player or a non-contact mechanism. Clifton, D. R., et al. (2018) concluded that the level of injuries was higher in students than in high school students, higher in competitions than in training.

In a study by Fraser, et al. [15] described injuries from contact with the ball in 11 sports (men's soccer, women's field hockey, women's volleyball, men's baseball, women's softball, men's and women's basketball, men's and women's lacrosse, men's and women's football) National Student Sports Association (NCAA) for the period 2009-2010 to 2014-2015 academic years. As a result of the study, 1123 injuries from contact with the ball were registered. The highest scores were women's softball, women's field hockey (7.71 / 10,000 student-athletes who participated in training or games (AE)) and men's baseball (7.20 / 10,000 student-athletes who participated in training or games (AE)). The majority of ballrelated injuries occurred on the hand / wrist $(32.7 \%)$ and head / face $(27.0 \%)$ and were diagnosed as strokes (30.5\%), sprains $(23.1 \%)$ and concussion (16.1\%). Among sexually comparable sports (eg, baseball / softball, basketball, and soccer), women had a higher rate of concussion diagnosed as concussion than men (ratio of injuries $=2.33 ; 95 \%)$. confidence interval $(\mathrm{CI})=1.63$, 3.33). More than half (51.0\%) of injuries from contact with the ball were associated with loss of time (ie time of restriction of participation, 24 hours), and $6.6 \%$ were severe (ie time of restriction of participation $>=21$ days). The most frequent severe injuries in contact with the ball were concussions $(n=18)$ and fractures of the fingers ( $n$ $=10$ ). Thus, the percentage of injuries from contact with the ball was highest in women's softball, women's field hockey and men's baseball. Although more than half were injuries without loss of time, serious injuries such as concussions and fractures were reported.

To prevent injuries, it is necessary to form rational movements in the most optimal way [1618]. That is why the technology of preserving the health of students - future specialists in physical education and sports should contain universal approaches to the process of learning technical skills, which will ensure the prevention of injuries and, consequently, the preservation of health. First, it is necessary to form in students the concept of biomechanically rational movements in general [19 $-21]$. Secondly, it is necessary to create conditions for students to master modern means of selfanalysis of movement techniques [19, 21]. Third, it is necessary to introduce into the learning process of students practical tools, exercises that will promote the formation of biomechanically rational movements in any sport, and thus prevent injuries $[8,9]$.

These provisions determine the great importance of research on the prevention of injuries of students - future professionals in physical education and sports, and based on these provisions, we can conclude that this work is timely and relevant.

Thus, in the analyzed works on traumatism of students, team sports were mainly investigated as the most susceptible to injuries. However, it is now also important to analyze injuries in other sports, which are increasing in popularity every year. Rock climbing can be chosen as such a sport for the following reasons: 1 - rock climbing is included in the program of the Olympic Games, it is becoming more and more popular among young people [22]; 2 - a large number of injuries are observed in rock climbing; 3 - there are currently no specific injury prevention programs in rock climbing [23-25].

The purpose: to develop and experimentally test the biomechanical technology of injury prevention of future specialists in physical education and sports in the process of professional training (rock climbing for example).

\section{Material and Methods}

\section{Participants and randomization}

The participants of this study were 84 male students engaged in amateur climbing in the cities of Ukraine (Kharkiv, Dnipropetrovsk, Lyuvov, Vinnytsia, Kamyanets-Podilsk, Kyiv) aged 18-19 years. All athletes were also students of physical education faculties of Ukrainian universities. All athletes gave written consent to participate in the experiment. The health of the athletes was checked during the first 2 weeks of the study with the help of regular medical examinations conducted by a doctor. Athletes were also observed for 6 months to assess baseline injury rates and baseline techniques of one-arm hang on one arm.

An independent statistician performed a parallel randomization of athletes into a control group and an intervention group using a random distribution method using an online random number generator program. As a result of randomization, 40 athletes were in the experimental group and 44 - in the control. 
The groups were compared with indicators of body length, body weight, experience of rock climbing and the number of injuries during the observed period of 6 months before the experiment. For all these indicators, the groups did not differ significantly from each other.

The body length of athletes in the control group was $172.5 \pm 8.5 \mathrm{~cm}$, body weight $-65.2 \pm 6.5$ $\mathrm{kg}$; the body length of the athletes of the experimental group was $173.4 \pm 8.7 \mathrm{~cm}$, body weight $-66.1 \pm 6.6 \mathrm{~kg}(\mathrm{p}>0.05)$.. No significant differences in the injury index in the control and experimental groups were found $(\mathrm{p}=0.385-0.729)$.

Both control and experimental groups consisted of novice athletes (amateurs), aged 18-19 years, males; body length of athletes of the control group was $172.5 \pm 8.5 \mathrm{~cm}$, body weight $-65.2 \pm 6.5$ $\mathrm{kg}$; the body length of the athletes of the experimental group was $173.4 \pm 8.7 \mathrm{~cm}$, body weight $-66.1 \pm 6.6 \mathrm{~kg}(\mathrm{p}>0.05)$. The groups trained according to the generally accepted plan 3-4 times a week, the number of training hours was the same in both groups. At the beginning and at the end of the pedagogical experiment, an analysis of the technique of performing the height on one arm was performed by experts in both groups. The number of injuries of the upper extremities in both groups was also recorded.

At the fourth stage of the study (August 2020 - December 2020) the analysis of the obtained data was carried out, the work was formalized.

\section{Injury registration method}

Cases of injuries and diseases of the upper extremities were registered during the year in the control and experimental groups. The following injuries were registered: injuries and diseases of the fingers, injuries and diseases of the elbow joint, injuries and diseases of the shoulder joint. Injuries were also registered by severity: minor, moderate, severe. Low complexity injuries include those that heal in less than 1 month, Medium complexity injuries that heal in 2-3 months, and High complexity injuries include those that heal within 6-12 months and can last a lifetime. Cases of injuries of the upper extremities were registered during the year in the control and experimental groups. Injuries of fingers were registered.

\section{Method of determining the risk of injury}

To determine the impact of the developed technology on the risk of injury, the following indicators were determined: risk (incidence) of injury, chance of injury, relative risk and odds ratio. Injury risk (incidence) was defined as the ratio of the number of injuries to the total number of athletes in the analyzed group. The relative risk (incidence rate ratio) was determined by the ratio of risk in the control group to the risk in the experimental group. The chance of injury was defined as the ratio of the number of injuries to the number of uninjured athletes in the analyzed group. The odds ratio was defined as the ratio of the chances of injury in the control group to the chances of injury in the experimental group.

\section{Intervention program}

As a result of analytical and creative work, a biomechanical technology for injury prevention in the training of specialists in physical education and sports was developed. The technology is developed, which contains 3 directions: 1 theoretical and methodical (creation of bases for understanding by students of mechanisms of formation of movements without risk of injury, formation at students of concept of biomechanically rational movements in general); 2 - analytical (providing students with knowledge about modern means of self-analysis of the level of technical skills); 3 - practical (students' mastery of practical means of injury prevention, ie, exercises that will promote the formation of biomechanically rational movements in any sport, and thus prevent injuries).

Theoretical and methodological direction involved mastering the basic knowledge of dynamic anatomy, which is the basis of biomechanics, the basic laws of motion control, understanding the causes and means of injury prevention in physical culture and sports.

In order to form a theoretical foundation for students in the process of formation and improvement of technical skills, an author's video manual on the basics of biomechanics of the musculoskeletal system was developed. The author's video manual is an illustration with an explanation of the biomechanical patterns of proper motor skills and injury prevention.

The author's video manual is entitled: "Biomechanics of the musculoskeletal system" (A.C. №№ 100612-100616 from 17.11.2020) and consists of 5 parts:

Part 1. Biomechanics of the musculoskeletal system. Basic concepts in biomechanics (A.C. № 100612 from 17.11.2020) (Fig. 1). 
Part 2. Biomechanics of the musculoskeletal system. Upper limb (A.C. № 100613 dated 17.11.2020) (Fig. 2).

Part 3. Biomechanics of the musculoskeletal system. Lower limb (A.C. № 100614 from 17.11.2020).

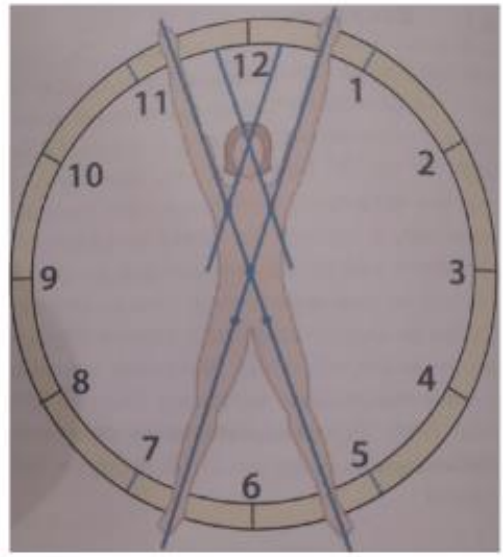

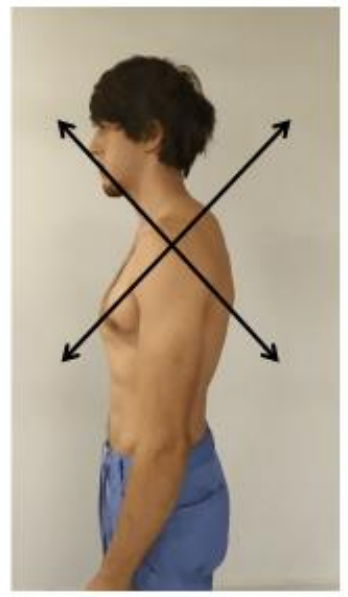

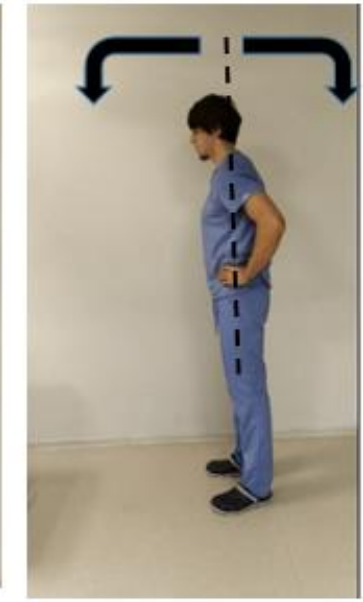

Fig. 1. Example of a slide of the first part of the author's textbook with an illustration of the pattern as part of the motor stereotype (source: the figure by the author)

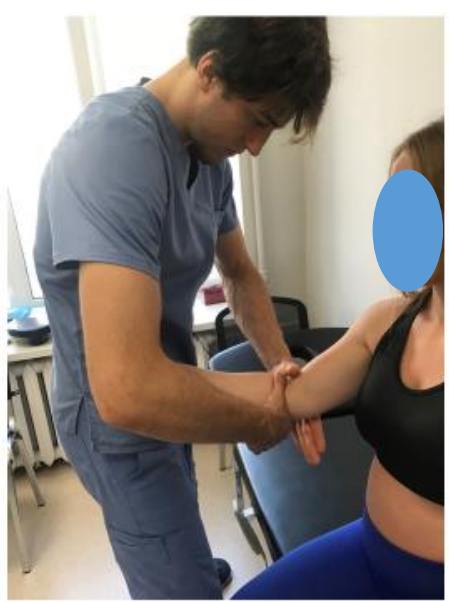

Fig. 2. Example of a slide of the second part of the author's textbook with an illustration of manual therapy techniques for injury prevention and recovery from injuries of the upper extremity belt (source: the figure by the author)

Theoretical classes on sports and pedagogical improvement explained to students the main tasks of studying the biomechanical foundations of the process of mastering technical skills.

As a result, students were given the opportunity to get a lot of interesting, relevant information and applied techniques for work and independent training.

The first part of "Biomechanics of the musculoskeletal system. Basic concepts in biomechanics "contains information about the authors, the tasks of the manual, which are as follows:

- Study of basic and clinically significant concepts of biomechanics [26, 27].

- Study of functional anatomy in motion models.

- Mastering and practicing methods of manual and functional therapy

Next, students are invited to determine their goals in classes on sports and pedagogical improvement. This is a necessary condition and the first step to create a conscious attitude of students 
to their functional state and injury prevention in both the chosen sport and other physical activities.

The next stage provides a definition of biomechanics as a science of the laws of mechanical motion in living systems, which studies the features of movements in the process of motor activity and exercise. The general task of biomechanics is to find perfect ways of motor actions and to teach / learn to perform them more effectively. The following are partial problems of biomechanics:

- Study and explanation of the human movements in a particular area of his motor activity.

- Study of the results of the motor task.

- Study of the conditions in which they are carried out.

- Based on all this - the development of effective movements, through learning and training.

In the analytical direction the algorithm of revealing of the basic kinematic parameters of various models of technics characteristic of students with various level of possession of technics of sports movements is developed.

The analytical direction of biomechanical technology of injury prevention provided for the introduction of modern means of analysis of the effectiveness of mastering motor skills in the initial process of physical education and sports. In particular, students were asked to learn a modern tool for video analysis of movement techniques the Kinovea program [28, 29]. The Kinovea sports video analysis program is now an effective, informative, easy-to-learn tool for improving the efficiency of students' acquisition of motor skills and injury prevention.

In the analytical classes, students were explained that for the prevention of injuries it is necessary to have modern tools not only qualitative but also quantitative analysis of movement technique. There are many different computer programs and video tools for this. One of the most common features is the Kinovea program.

In the future, students were invited to master working with this program.

In the practical direction the principles of application of means for prevention of traumatism are defined:

1 - strengthening of the muscles participating in performance of the movement;

2 - the formation of functional movement, coordinated work of the muscles of the torso, upper and lower extremities.

In this directions, developed and systematized tools to prevent injuries to students future professionals in physical education and sports [30 -32].

All means are conditionally divided into two groups: means from a sport and means specific to physical therapy. Physical therapy is used in an unconventional way: to improve movement technique and to prevent injuries. We have applied following means of practical exercises for injury prevention in the process of training specialists in physical education and sports on the example of climbing.

The exercises were based on neuromuscular training $[10,19]$ with movements in a closed kinematic chain and exercises in an eccentric mode [33, 34].

Exercises specific to physical therapy were aimed at the formation of functional movements. The basis of physical therapy exercises was made up of movements aimed at coordinated interaction of the patterns of the shoulder, scapula, pelvis and trunk.

\section{Statistical analysis}

The values of the measured angles at the point of stable fixation of the height were compared on the basis of 20 measurements for each model of technology using the Student's method for odd samples.

To determine the impact of the developed technology on the risk of injury, the following indicators were determined: risk (incidence) of injury, chance of injury, relative risk and odds ratio using the computer program SPSS-17, Crosstabs option.

For the entire sample, we used the exact Fisher test and the Pearson $\chi$-square test to compare the injury rate between the intervention groups and the control group. We calculated the number needed for training to prevent 1 injury as the inverse of the difference between the percentages of injured players in the control and experimental $\begin{array}{llll}\text { groups. We considered bilateral } \mathrm{P} & <0.05\end{array}$ statistically significant.

We presented the Injury rate indicates as the number of injuries per $1000 \mathrm{NPPs}$, and we defined the $\mathrm{AE}$ as the number of athletes multiplied by the number of all training sessions and competitions in which they participated $(\mathrm{AE}=$ athlete*exposure (training sessions, competitions)). In our case, the number of trainings and competitions was the same in the control and experimental groups and was 75 before the experiment and 150 during the experiment. The number of students - climbers in our case was 40 for the experimental group and 44 - for the control). The value of the Injury rate was defined as - the number of injuries 1000 AEs. 
Significance of differences in the number and risk of injuries between the control and experimental groups was determined by the Fisher exact test and using the Pearson $\chi$-square test.

Injury risk (incidence) was defined as the ratio of the number of injuries to the total number of athletes in the analyzed group. Relative risk (incidence rate ratio) was determined by the ratio of risk in the control group to the risk in the experimental group. The chance of injury was defined as the ratio of the number of injuries to the number of uninjured athletes in the analyzed group [35]. The relative chance (Odds Ratio) was defined as the ratio of the chances of injury in the control group to the chances of injury in the experimental group [35]. These indicators were determined separately for all analyzed types of finger injuries (low, medium and severe).

\section{Results}

The total number of all registered finger injuries during 1 year of the experiment was 33 in the control group and 9 in the experimental group. The number of AEs during 1 year of the experiment was 6600 in the control and 6000 in the experimental groups. Injury rate per 1000 AEs of all registered finger injuries in the control group during the 1 year of the experiment was 5.5 (95\% $\mathrm{Ci}, 1.061 ;$ 9.267), in the experimental group - 1.364 (95\% Ci, 0.032; 2.375), $\mathrm{P}<0.001$.

The injury rate of mild finger injuries per 1000 AEs during 1 year of the experiment in the control group was $1.97(95 \% \mathrm{Ci}, 1.061 ; 2.303)$, in the experimental group - $0.83(95 \% \mathrm{Ci}, 0.068$; 0.978 ). The incidence rate ratio for cohort (injuries $=$ no) for mild shoulder injuries was 0.805 (0.643; 1.00). We also found that the Injury rate of moderate finger injuries per 1000 AEs during 1 year of the experiment in the control group was $1.67(95 \% \mathrm{Ci}, 0.247 ; 1.783)$, in the experimental group - $0.50(95 \% \mathrm{Ci}, 0.088 ; 1.182)$. The incidence rate ratio for cohort (injuries $=$ no) for moderate finger injuries was $0.811(0.669 ; 0.982 ; \mathrm{P}=0.030)$. Our study also showed that the Injury rate of severe finger injuries per thousand AEs during 1 year of the experiment in the control group was 1.36 (95\% CI, 0.134; 1.685), in the experimental group - 0.17 ( $95 \%$ CI, $0.065 ; 1.225)$. The incidence rate ratio for cohort (injuries $=$ no) for severe finger injuries was 0.816 (0.697; 0.955; $\mathrm{P}=0.011)$ (Table 1).

The incidence (risk) of finger injuries of low complexity in the control group is 0.23 , in the experimental - 0.10 ; the chances of getting a finger injury of low complexity in the control group is 0.419 , in the experimental -0.143 . The relative risk (control group / experimental group) to get a injury of fingers of low complexity in the control group is higher in 2.364 (95\% CI $=0.925-6.041, \mathrm{P}>0,05)$ times in comparison with experimental (tab. 1, ). Relative risk - the probability of injury (experimental group / control group) is equal to $0.805(95 \%$ CI $=0.643-1.008, \mathrm{P}>0.05)$. The relative chance of getting a finger injury of low complexity in the control group is 2.935 times higher (95\% CI $=0.940-9.170, \mathrm{P}>0.05)$ compared with the experimental (Table 1).

The incidence (risk) of finger injuries of medium complexity in the control group is 0.250 , in the experimental - 0.075; the chance of getting a finger injury of medium complexity in the control group is 0.333 , in the experimental - 0.081 . The relative risk (control group / experimental group) to get a finger injury of medium complexity in the control group is higher by 3.333 times $(95 \% \mathrm{CI}=$ 1.001-11.096, P (Fisher) $=0.030$ ) compared to the experimental. Relative risk - the probability of injury (experimental group / control group) is equal to $0.811(95 \% \mathrm{CI}=0.669-0.982, \mathrm{P}$ (Fisher) $=$ 0.030 ). The relative chance of getting a finger injury of medium complexity in the control group is 4,111 times higher (95\% CI $=1.055-16.020, \mathrm{P}$ $\left.\left(\chi^{2}\right)=0.041\right)$ compared with the experimental (Table 1).

The incidence (risk) of finger injuries of high complexity in the control group is 0.205 , in the experimental - 0.025; the chances of getting a finger injury of high complexity in the control group is equal to 0.257 , in the experimental -0.026 . The relative risk (control group / experimental group) to get a finger injury of high complexity in the control group is 8,182 times higher $(95 \% \mathrm{CI}=$ 1.084-61.749, $\mathrm{P}$ (Fisher) $=0.011)$ compared to the experimental. Relative risk - the probability of injury (experimental group / control group) is $0.816(95 \% \mathrm{CI}=0.697-0.955$, $\mathrm{P}($ Fisher $)=0.011)$. The relative chance of getting a finger injury of high complexity in the control group is 10,029 times higher $(95 \% \mathrm{CI}=1.209-83.201, \mathrm{P}(\chi 2)=$ $0.016)$ compared with the experimental (Table 1).

\section{Discussion}

As the analysis of the literature has shown, our study is one of the first to develop programs for the prevention of injuries for students - future specialists in the field of physical education and sports. In addition, our study is one of the first on injury prevention for climbers. Our technology for the prevention of injuries of students studying in the specialty "Physical Education and Sports" 
involves 3 directions: theoretical and methodological, analytical and practical. As the study showed, the application of the developed technology is effective for the prevention of injuries of students - rock climbers, future specialists in physical education and sports. Thus, the goal of the work was achieved: the technology of prevention of injuries of students - future specialists in physical education and sports - was developed and experimentally substantiated. In our study, we presented the results of the application of the developed technology for the prevention of finger injuries of rock climbers - students of the faculties of physical education and sports.

Indicators of finger injuries in the control $(n=44)$ and experimental $(n=40)$ groups

Table 1

\begin{tabular}{|c|c|c|c|c|c|c|c|c|c|c|c|c|}
\hline \multirow[t]{2}{*}{ Group } & \multicolumn{4}{|c|}{ Low complexity } & \multicolumn{4}{|c|}{ Medium complexity } & \multicolumn{4}{|c|}{ High complexity } \\
\hline & Yes* & No * & $\begin{array}{c}\text { Incidence } \\
\text { (risk) of } \\
\text { injuries }\end{array}$ & $\begin{array}{c}\text { Chance of } \\
\text { injury }\end{array}$ & Yes & No & $\begin{array}{l}\text { Incidence } \\
\text { (risk) of } \\
\text { injuries }\end{array}$ & $\begin{array}{c}\text { Chance of } \\
\text { injury }\end{array}$ & Yes & No & $\begin{array}{c}\text { Incidence } \\
\text { (risk) of } \\
\text { injuries }\end{array}$ & $\begin{array}{l}\text { Chance } \\
\text { of injury }\end{array}$ \\
\hline C & 13 & 31 & 0.23 & 0.419 & 11 & 33 & 0.250 & 0.333 & 9 & 35 & 0.205 & 0.257 \\
\hline$E$ & 5 & 35 & 0.10 & 0.143 & 3 & 37 & 0.075 & 0.081 & 1 & 39 & 0.025 & 0.026 \\
\hline $\begin{array}{c}\mathrm{IRR}(\mathrm{Cl}) \\
\mathrm{P}^{\mathrm{a}}\end{array}$ & \multicolumn{4}{|c|}{$2.364(0.925 ; 6.041)$} & \multicolumn{4}{|c|}{$\begin{array}{c}3.333(1.001 ; 11.096) \\
\text { P(Fisher })=0.030\end{array}$} & \multicolumn{4}{|c|}{$\begin{array}{c}8.182(1,084 ; 61.749) \\
\text { P (Fisher) }=0.011\end{array}$} \\
\hline $\begin{array}{c}\mathrm{OR}(\mathrm{Cl}) \\
\mathrm{P}^{\mathrm{a}}\end{array}$ & \multicolumn{4}{|c|}{$2.935(0.940 ; 9.170)$} & \multicolumn{4}{|c|}{$\begin{array}{c}4.111(1.055 ; 16.020) \\
P\left(\chi^{2}\right)=0.041\end{array}$} & \multicolumn{4}{|c|}{$\begin{array}{c}10.029(1.209 ; 83.201) \\
p\left(\chi^{2}\right)=0.016\end{array}$} \\
\hline
\end{tabular}

Notes: C-control group; E - experimental group; * - Yes - the number of people injured; No - the number of people who were not injured; IRR (incidence rate ratio) - the ratio of the value of the risk of injury in the control group to the value of risk in the experimental group; OR (Odds Ratio) - the ratio of the chances of injury in the control group to the value in the experimental group; $\mathrm{Cl}$ - confidence interval (lower limit. Upper limit); and - only reliable values of $\mathrm{P}$ are presented; $\mathrm{P}$ (Fisher) - was determined by the exact Fisher test; $\mathrm{P}(\mathrm{X} 2)$ was determined by the Pearson $\chi$-square test

It should be noted that we have confirmed our previous studies on injury prevention for amateur climbers [32]. The work [32] showed that the use of neuromuscular training is effective for the prevention of finger injuries in climbers. The study presented in this work has shown a higher efficiency of the use of complex technology for the prevention of finger injuries of rock climbers students. We believe that the great efficiency of the developed technology is due to its complex nature: it contains not only neuromuscular training, but also theoretical, methodological and analytical components. The educational component is very important for the students - climbers' conscious use of the proposed practical exercises [19]. In addition, the analytical component is important for the quantitative analysis of the technical features of the main elements of the sport. It is the integrated approach that determined the high efficiency of the use of biomechanical technology for preventing injuries of students - rock climbers, future specialists in physical education and sports. In addition, the study also confirmed our data presented in previous works on the effectiveness of the use of exercises in a closed kinematic chain and eccentric exercises for the prevention of shoulder injuries $[30,31]$. In the study presented in this paper, technologies of a complex nature are shown. The theoretical, methodological and analytical aspects complement the practical, making up a coherent whole of understanding, application and ability to analyze. This, in our opinion, is especially important for students - future specialists in physical education and sports.

Our research has also confirmed the findings of other scientists dealing with the problem of student injuries. So, in many works it is shown that injuries received as a result of students' sports activities are a real problem. So, Jin [36] found a high number of injuries in college football students. Similar results were obtained by Kahlenberg, et al. [37]. It was found that every student is an athlete. on average engaged in 1.6 different sports. The average number of hours of sports per year was 504.3 and 371.6 hours, respectively. The average total number of sports injuries received by athletes was 1.7 per participant. $80.8 \%$ of respondents reported having suffered at least one sports injury. Thus, the number of injuries in students engaged in sports is high.

Kerr, et al. [38] data on injuries and impacts collected on 27 sports using the National Network for Sports Treatment, Injuries and 
Outcomes (NATION). The results provided by certified sports coaches (AT) for the collection of data on injuries of athletes (AE) in training and competitions in 27 sports in the period from $2011 / 2012$ to $2013 / 2014$ were analyzed. It was found that most of the 47,014 injuries were injuries of the ankle and knee joints (82.8\%). Among boys in sports, the injury rate was highest in football (3.27 / $1000 \mathrm{AE})$ and wrestling (2.43 / $1000 \mathrm{AE})$; The number of ankle and knee injuries was also highest in football (15.29 / $1000 \mathrm{AE})$ and wrestling (11.62 / 1000 AE). Among women's sports, the injury rate was highest in football (1.97 / 1000AE) and basketball (1.76 / 1000AE); The number of ankle and knee injuries was highest in field and lacrosse field hockey (both 11.32 / $1000 \mathrm{AE}$ ).

Our research has shown that rock climbing is also a dangerous sport in terms of upper limb injuries. Given its growing popularity among young people, the development and substantiation of a technology for the prevention of climbers' injuries is timely. This is especially true for students - future specialists in physical education and sports, since their task is not only to learn how to train without injuries, but also then to carry the knowledge gained to their future students.

\section{Conclusions}

1. The biomechanical technology for injury prevention in the training of specialists in physical education and sports has been developed on rock climbing for example. Developed biomechanical technology for injury prevention contains 3 areas: 1 - theoretical and methodological (creating a basis for students to understand the mechanisms of movement without risk of injury; concept of biomechanically rational movements in general); 2 - analytical (providing students with knowledge about modern means of self-analysis of the level of technical skills); 3 - practical (students' mastery of practical means of injury prevention, exercises that will promote the formation of biomechanically rational movements in any sport, and thus prevent injury).

2. The applied technology of injury prevention significantly influences both the reduction of the number of injuries of athletes future specialists on the physical education and sports (on rock climbing for example). It is established that the application of the developed technology of injury prevention reduces the risk of finger injuries: low complexity - in 2.364 times $(95 \% \mathrm{CI}=0.925-6.041, \mathrm{P}>0,05)$ times; medium complexity - in 3.333 times $(95 \% \mathrm{CI}=1.001$ 11.096, P $($ Fisher $)=0.030)$; high complexity - in 8.182 times $(95 \% \mathrm{CI}=1.084-61.749, \mathrm{P}($ Fisher $)=$ $0.011)$.

\section{Acknowledgements}

The authors are very grateful to all the athletes and coaches who took part in the experiment.

The study was conducted according to: research work on the topic of the Department of Olympic and Professional Sports, Sports Games and Tourism of H.S. Skovoroda Kharkiv National Pedagogical University for 2021-2026: "Development and substantiation of technologies for health promotion and harmonious development of people of different ages and social groups" (№ state registration: 0121U110053).

\section{Conflict of interest}

Authors state that there is no conflict of interest.

\section{References}

1. Goossens L, De Ridder R, Cardon G, Witvrouw E, Verrelst $R$, De Clercq D. Injury prevention in physical education teacher education students: Lessons from sports. A systematic review. European Physical Education Review. 2019;25(1):156-73.. doi:10.1177/1356336x17711675

2. Kozina ZL, Goloborodko YA, Boichuk YD, Sobko IM, Repko OO, Bazilyuk TA, et.al. The influence of a special technique for developing coordination abilities on the level of technical preparedness and development of psycho-physiological functions of young volleyball players 14-16 years of age. Journal of Physical Education and Sport. 2018; 18(3):14451454. DOI:10.7752/jpes.2018.03214

3. Iermakov SS. Kozina ZhL. Ceslitska M. Mushketa R, Krzheminski M, Stankevich B. Razrabotka kompyuternyih programm dlya opredeleniya psihofiziologicheskih vozmozhnostey i svoystv nervnoy sistemyi lyudey $\mathrm{s}$ raznyim urovnem fizicheskoy aktivnosti [Computer program development for determination of psychophysiological possibilities and properties of thenervous system of people with the different level 
of physicalactivity]. Zdorov'â. sport. reabilitaciâa [Health. sport, rehabilitation]. 2016;2(1):14-19.

4. Brown S, Hall EE. Evaluating The Effectiveness Of Applying Grief-Response Models To Sport Injury In Collegiate Student-Athletes. Medicine and Science in Sports and Exercise. 2018;50(5):325-..

5. Hao FX, Tang CJ, Huang DY, Cheng BS. Pre-test into Legal Issues on the School Sports Injury Accidents. In: Zhang TB, editor. Future Computer, Communication, Control and Automation. Advances in Intelligent and Soft Computing. 1192011. p. 2359.

6. Heaney CA, Rostron CL, Walker NC, Green AJK. Is there a link between previous exposure to sport injury psychology education and UK sport injury rehabilitation professionals' attitudes and behaviour towards sport psychology? Physical Therapy in Sport. doi:10.1016/j.ptsp.2016.08.006

7. Narvaez WCM, Maldonado GEP, Gomez DIO, Cando EOC. Perception of students on the possible impact of sports injuries on academic performance. Revista Publicando. 2017;4(12):857-64.

8. Lynall RC, Gardner EC, Paolucci J, Currie DW, Knowles SB, Pierpoint LA, et al. The First Decade of Web-Based Sports Injury Surveillance: Descriptive Epidemiology of Injuries in US High School Girls' Field Hockey (2008-2009 Through 2013-2014) and National Collegiate Athletic Association Women's Field Hockey (2004-2005 Through 2013-2014). Journal of Athletic Training. 2018;53(10):938-49.

9. McLoughlin RJ, Green J, Nazarey PP, Hirsh MP, Cleary M, Aidlen JT. The risk of snow sport injury in pediatric patients. American Journal of Emergency Medicine. 2019;37(3):439-43.

10. McCann R, Cortes N, Van Lunen B, Greska E, Ringleb S, Onate J. Neuromuscular Changes Following an Injury Prevention Program for ACL Injuries. International Journal of Athletic Therapy \& Training.

2011;16(4):16-20. doi:10.1123/ijatt.16.4.16

11. McLoughlin RJ, Green J, Nazarey PP, Hirsh MP, Cleary M, Aidlen JT. The risk of snow sport injury in pediatric patients. American Journal of Emergency Medicine. 2019;37(3):439-43.

12. Asperti AM, Fernandes TL, Marinho IM, Pedrinelli A, Hernandez AJ. Sports injuries among amateur athletes at a Brazilian University. Acta Ortopedica Brasileira. 2017;25(2):93-8. doi:10.1590/1413785220172502165651

13. Burchard R, Stolpp A, Kratz T, Efe T, Soost C, Forreiter C, et al. School sport-associated injuries in adolescents: A single center experience. Technology and Health Care. 2017;25(6):1053-9.

14. Clifton DR, Hertel J, Onate JA, Currie DW, Pierpoint LA, Wasserman EB, et al. The First Decade of Web-Based Sports Injury Surveillance: Descriptive Epidemiology of Injuries in US High School Girls' Basketball (2005-2006 Through 20132014) and National Collegiate Athletic Association Women's Basketball (2004-2005 Through 20132014). Journal of Athletic Training. 2018;53(11):1037-48.doi:10.4085/1062-6050-150-
17

15. Fraser MA, Grooms DR, Guskiewicz KM, Kerr ZY. Ball-Contact Injuries in 11 National Collegiate Athletic Association Sports: The Injury Surveillance Program, 2009-2010 Through 2014-2015. Journal of Athletic Training. 2017;52(7):698-707.

16. Chan DKC, Zhang L, Lee ASY, Hagger MS. Reciprocal relations between autonomous motivation from self-determination theory and social cognition constructs from the theory of planned behavior: A cross-lagged panel design in sport injury prevention. Psychology of Sport and Exercise. 2020;48.

17. Liang JX, Zhang B. Design and Practice Research of Sports Injury Network Consulting System. In: Kim YH, Yarlagadda P, editors. Materials, Mechanical and Manufacturing Engineering. Advanced Materials Research. 8422014. p. 678-81.

18. Yin JX, Gao Y, Lei L. Significance of Injury Protection and Data Mining Policy Coordination in Promoting Students' Sports Consciousness. Basic \& Clinical Pharmacology \& Toxicology. 2020;127:214-.

19. LaBella CR, Huxford MR, Grissom J, et al. Effect of neuromuscular warm-up on injuries in female soccer and basketball athletes in urban public high schools. Archives of Pediatrics and Adolescent Medicine. 2011;165(11):1033-1040.

20. Parkkari J, Taanila H, Suni J, et al. Neuromuscular training with injury prevention counseling to decrease the risk of acute musculoskeletal injury in young men during military service: a populationbased, randomized study. BMC Medicine. 2011;9(1):35.

21. Pasanen K, Parkkari J, Pasanen M, et al. Neuromuscular training and the risk of leg injuries in female floorball players: cluster randomised controlled study. British Journal of Sports Medicine. 2008;42:802-805.

22. Lutter C, El-Sheikh Y, Schoffl I, Schoffl V. Sport climbing: medical considerations for this new Olympic discipline. British Journal of Sports Medicine. 2017;51(1):2-U5. doi:10.1136/bjsports2016-096871

23. Hochholzer T, Schoffl VR. Epiphyseal fractures of the finger middle joints in young sport climbers. Wilderness \& Environmental Medicine. 2005;16(3):139-142. doi:10.1580/pr15-04.1

24. Jones G, Asghar A, Llewellyn DJ. The epidemiology of rock-climbing injuries. $\mathrm{Br} J$ Sports Med. 2008;42(9):773-8. doi: 10.1136/bjsm.2007.037978

25. Jones G, Johnson MI. A Critical Review of the Incidence and Risk Factors for Finger Injuries in Rock Climbing. Current Sports Medicine Reports. 2016;15(6):400-9.

26. Bernstein NA. The coordination and regulation of movements. Oxford : Pergamon Press. 1967.

27. Zinchenko VP. Nikolai Bernshtein: From reflexes to models of the future. Voprosy Psikhologii. 2004(6):123-7.

28. Kozin S, Safronov D, Kozina Z, Kniaz H, Proskurnia O, Prontenko K, Lahno O, Goncharenko V, Kholodniy A. Comparative biomechanical characteristics of one-arm hang in climbing for 
beginners and qualified athletes. Acta of Bioengineering and Biomechanics. 2020;22(1):5767.DOI: 10.37190/ABB-01440-2019-03.

29. Kozin SV. Biomechanical substantiation of the technique of hanging in rock climbing. Zdorov'â, sport, reabilitaciâ [Health. sport, rehabilitation]. 2019; 5(1): 25-35. doi: 10.34142/HSR.2019.05.01.03

30. Kozin S, Cretu M, Kozina Z, Chernozub A, Ryepko O, Shepelenko T, Sobko I, Oleksiuk M. Application closed kinematic chain exercises with eccentric and strength exercises for the shoulder injuries prevention in student rock climbers: a randomized controlled trial. Acta Bioeng Biomech. 2021;23(2):54-62. DOI: 10.37190/ABB-018282021-01.

31. Kozin S, Kozina Z, Korobeinik V. Injury prevention of rock climbers (Neuro-muscular training for injury prevention of rock climbers based on biomechanical analysis of the one-arm hang). Encyclopedia platform (ISSN 23093366), Video,

21.04.2021. https://encyclopedia.pub/9802

32. Kozin S, Kozina Z, Korobeinik V, Cieślicka M, Muszkieta R, Ryepko O, Boychuk Yu, Evtifieva I, Bejtka M. Neuro-muscular training for injury prevention of students-rock climbers studying in the specialty "Physical Education and Sports": a randomized study. Journal of Physical Education and Sport. 2021;21(Suppl. issue 2):1251 - 1259.

33. Coppack RJ, Etherington J, Wills AK. The effects of exercise for the prevention of overuse anterior knee pain. The American Journal of Sports Medicine. 2011;39(5):940-948.

34. Augustsson RJ, Esko A, Thomee R, Svantesson U. Weight training of the thigh muscles using closed vs. open kinetic chain exercises: A comparison of performance enhancement. Journal of Orthopaedic \& Sports Physical Therapy, 1997;27(1):3-8. doi:10.2519/jospt.1998.27.1.3

35. Knowles S, Marshall SW, Guskiewicz KM. Estimating rates and risks in sports injury research. $J$ Athl Train. 2006;41:207-215.

36. Jin J. Analysis of sports injuries and the causes in football teaching of college students. Basic \& Clinical Pharmacology \& Toxicology. 2020;126:412.

37. Kahlenberg CA, Nair R, Monroe E, Terry MA, Edwards SL. Incidence of injury based on sports participation in high school athletes. Physician and Sportsmedicine. 2016;44(3):269-73.

38. Kerr ZY, Roos KG, Djoko A, Dompier TP, Marshall SW. Rankings of High School Sports Injury Rates Differ Based on Time Loss Assessments. Clinical Journal of Sport Medicine. 2017;27(6):548-51

\section{Information about the authors}

\section{Kozin S.V.}

kozin.serenya@gmail.com

http://orcid.org/0000-0003-1351-664X

Aimed Klnik (Israel) - Alef Clinic (Kharkiv, Ukraine)

Pushkinskaya st., 32, Kharkiv, Ukraine

\section{Інформація про автора}

\section{Козін С.В.}

kozin.serenya@gmail.com

http://orcid.org/0000-0003-1351-664X

Аймед клініка (Ізраіль) - Алеф - клініка (Україна)

вул. Пушкінська, 32, Харків, Україна

\section{Информация об авторе}

\section{Козин С.В.}

kozin.serenya@gmail.com

http://orcid.org/0000-0003-1351-664X

Аймед - клиника (Израиль) - Алеф - клиника (Украина)

Пушкинская ул., 32, Харьков, Украина

This work is licensed under a Creative Commons Attribution 4.0 International License (CC BY 4.0)

Received: 2021-04-07 Accepted: 2021-05-12 Published: 2021-06-25 